"This is the peer reviewed version of the following article: Wilkinson, Stephen (2017) A perfect impasse? Cuba's move towards the market and the U.S. move towards Cuba, 37(1), which has been published in final form at https://doi.org/10.1111/ecaf.12221. This article may be used for noncommercial purposes in accordance with Wiley Terms and Conditions for Use of Self-Archived Versions." 


\title{
A perfect impasse? Cuba's move towards the market and the U.S. move towards Cuba
}

\author{
Dr Stephen Wilkinson, University of Buckingham
}

\begin{abstract}
This article firstly analyses the internal economic trajectory of the Cuban economic reforms and evaluates their effectiveness in delivering the extensive and intensive development needed to resolve Cuba's structural and economic imbalances. It concludes that without the lifting of the U.S. economic sanctions, success will at best be only partial, with serious implications for long-term stability. The article then evaluates the reasons for the U.S. economic sanctions against Cuba and argues that while the embargo policy might have failed to topple the Cuban communist regime, it has served other, largely unacknowledged, purposes that are important in understanding why the policy has persisted. The article concludes by suggesting that the U.S. is not likely to jettison the sanctions regime while Cuba remains a single party, state led economic system. At the same time, Cuba is not likely to jettison its single party system while the sanctions remain.
\end{abstract}

Key words: Cuba, United States, economy, embargo, economic sanctions

\section{Introduction}

The recent death of Cuban leader Fidel Castro and the election of Donald Trump to the U.S. presidency has once again focused attention on a thorny question in Washington's backyard: What to do about Cuba? Despite adopting some economically liberalising reforms in recent years, the island remains the only single party Communist state in the Western Hemisphere and steadfastly refuses to politically transition towards democracy. It was partly in response to this stubbornness that President Barack Obama made a dramatic switch in US policy in 2014 and sought to end decades of hostility in the hope of creating leverage that might induce such a transition in Havana. Ordinarily, the death of Washington's nemesis, Fidel Castro, would be seen as a development that would enhance the possibility of rapprochement between the two adversaries. However, now that Donald Trump has entered the White House and Republicans have won both Houses of Congress, such optimism seems misplaced.

This is a pity because Raúl Castro, the current Cuban president, since taking full office in 2007, has been leading a gradual but radical overhaul of the economic system that is redefining the relationship between the state, the individual, and society. While Castro insists that the aim is to improve the socialist system, the reform process in Cuba is arguably the most likely means by which Cuba will become a democracy in the future.

To his credit, President Barack Obama seemed to acknowledge this. He was candid in his assessment of the United States' long-standing policy towards Cuba, stating publicly that the embargo had, 'failed to advance our interests' (Obama, 2014). His decision to relax as far as possible the almost six decades old embargo effected a sea change in U.S.-Cuba relations with the reestablishment of full diplomatic missions in the two capitals and a series of negotiations aimed at arriving at an end of economic sanctions and the 'normalisation' of 
their relationship. It remains to be seen how President Trump will deal with this legacy. In his inimitably contradictory style, at the start of his campaign he signalled that he would do more than Obama to open up relations and then, on the day that Fidel Castro's death was announced, he issued a statement saying that he would reverse Obama's reforms, "unless the Castro regime meets our demands - not my demands, our demands.". In saying this, Mr Trump effectively voiced the central argument under discussion here. (Wootson Jr. 2016)

This article establishes an inversely symbiotic relationship between the policies of the two neighbours. Firstly, it analyses the internal economic trajectory of the recent Cuban economic reforms and evaluates their effectiveness in delivering the extensive and intensive development needed to resolve Cuba's structural and economic imbalances. It concludes that without the lifting of the U.S. economic sanctions, its success will at best be only partial, with serious implications for long-term stability.

The article then examines the reasons and arguments for the establishment and maintenance of the U.S. economic sanctions against Cuba. It argues that while the embargo policy might have unquestionably failed to topple the Cuban communist regime, it has served other, largely unacknowledged, purposes that are important in understanding why the policy has survived for as long as it has.

The article concludes by arguing that the U.S. is not likely to jettison the sanctions regime while Cuba remains a single party, state led economic system. At the same time, Cuba is not likely to jettison its single party system while the sanctions remain. Thus, while Cuba's move to the market engendered a softening of U.S. sanctions under Obama, the embargo policy is likely to be retained under Trump unless Cuba goes the whole way towards a free market liberal democratic model. At the same time, Cuba is unlikely to do that unless there is a substantial alteration in the domestic popular will but this is less likely to happen unless the economy improves. Paradoxically, this cannot occur unless the embargo is lifted. The countries are locked in an impasse from which it extremely difficult if not impossible to break.

\section{Cuba's move to the market}

As we approach the tenth anniversary of the launch of Cuba's project to reform its economic system, it remains a work in progress. Despite the adoption of some 315 'Guidelines' in 2011 it does not yet have a complete definition. The official name for the process that translates as "the Actualization (or updating) of the Cuban social and economic model," does not quite convince. It suggests a degree of official cohesion that perhaps is not there and tends to overlook what could be rather serious ramifications for society and politics. (Communist Party of Cuba, 2011)

By adopting market solutions to the economic problems facing the Cuban economy, some fear that the term 'socialism' is being applied to something that is no longer recognisable as anything that Karl Marx envisaged. To give one example, the Cuban plan has included the permission for small privately owned enterprises and private farmers to employ workers. (MercoPress, 2016) This reintroduces the possibility of the hitherto Marxist taboo of 'man's 
exploitation by man.' In another move, the ceiling on earnings has been removed, making it possible for individuals to become rich. Thus Cuban socialism no longer embraces the goal of egalitarianism and instead the leadership talks of "equality of opportunity." (Communist Party of Cuba, 2011) That being said, the government has stopped short of wholescale privatisation. Large areas of the economy are still in state ownership, while many enterprises that were once state-owned have been or are set to become, not individually-owned enterprises, but cooperatives. The 'model' that is emerging is a therefore a hybrid. (Feinberg and Piccone eds. 2014)

It should be recalled that this hybrid has been a long time in the making and the skeleton of what is being fleshed out now was first erected in mid-1990s when, after the collapse of the Soviet Union, Cuba adopted a series of reforms that opened up some areas of the economy to foreign investment, permitted the circulation of the U.S. dollar and allowed for some forms of self-employment. These 'market solutions' were considered by some as emergency measures to alleviate the immediate problems caused by the economic crisis that would be reversed when the state would be able to return to the egalitarian and completely government controlled system that had been in place since the early 1970s. However, such assumptions were erroneous because the centralised system, which copied the organisational structures of Soviet central planning, was a failure. It may have succeeded in creating one of the most egalitarian societies in the world, with an extremely effective welfare state and education system (Jones, 2016), but it failed developmentally by leaving the island with a woefully unbalanced productive base and a grossly inadequate physical infrastructure. ${ }^{1}$ Despite a upturn of fortune in the early 2000s as a result of a beneficial relationship with Venezuela, Cuba's recovery and growth has been insufficient. There could be no return to the old system, as its chief architect, Fidel Castro frankly acknowledged in 2010. (Goldberg, 2010).

Thus what we have witnessed is a series of cumulative measures that have buried any idea of a return to that centralised system. Most prominently these measures have included agricultural reform, the formalization of a progressive tax code, and the shrinking of the size of state payroll by allowing for a greater number of small businesses and self-employed. Recently, there has been the introduction of credit and loans to small entrepreneurs, the permission to sell houses and cars privately, the establishment of wholesale markets and cooperativisation. (Feinberg and Piccone eds. 2014)

These changes have prompted comparisons with China and Vietnam, but Cuba, while learning from both these examples, is not precisely copying them. Detailed below are the reasons why the island's unique demographic, geographic, and economic features, set it quite apart. Demographically, Cuba has the challenge of a largely urbanised but rapidly ageing population. Geographically, it has to grapple with a close proximity to the United States and their abrasive asymmetrical relationship. Economically, Cuba has the imbalance of having of a large store of highly developed human capital, an advanced, comprehensive welfare state (with the

\footnotetext{
${ }^{1}$ In 1989, Cuba remained still a monoculture economy dependent almost entirely for its foreign earnings on the export of sugar and derivatives to the former COMECON countries. In terms of infrastructure the national central highway, a project started under the dictator Batista was left unfinished. Even today, transport between Havana and the island's second city Santiago has to proceed for half the $750 \mathrm{~km}$ journey down a potholed single lane trunk road that passes through every city centre en-route. A journey that should take two to three hours can take more than 12 .
} 
educational/scientific systems to maintain it) existing alongside a woefully underdeveloped productive base and dilapidated physical infrastructure, making it impossible to afford. All these factors mean that the characteristics of the 'Cuban model' differ from the Chinese. (Wilkinson, 2012)

Not that there is any real agreement as to what the Chinese 'model' is. China specialists such as Shaun Breslin have explained the disagreement about what exactly is going on in China and the way that we in the 'West' have largely constructed a perception of a Chinese 'model' that does not really exist. So it is naïve to suggest that Cuba is 'copying' what China is doing. Rather it is more accurate to say that Cuba has adopted some of the methods or approaches that China and Vietnam have taken. (Breslin, 2011) These are broadly termed by Breslin as 'pragmatism', 'gradualism', 'experimentalism' 'managed globalization' and 'strong government.' In this sense, the Cuban 'model' resembles the other so-called 'market socialist' experiments in seeking to retain a very strong state that maintains macro-economic control. It seeks to retain ownership of the financial institutions and the key strategic industries while creating a space for the market as a driver of productivity and a mechanism for distribution at the micro-level. Ideologically, this state-led developmental strategy is justified as being in the national interest and the best means of retaining sovereignty in the face of the U.S. hegemon.

This explains why Cuba's reform process is slow and sometimes inconsistent and often criticised (even by the leadership) as insufficient to address its citizens' economic difficulties. (Córdoba, 2016) This gradualism, however, has reason and purpose. The response of the Cuban leadership has required strategic thinking and considerable debate, not least a public consultation process that took some two years to complete and involved more than three million citizens. (Ludlam, 2012) Raúl Castro has said the process of change is essential and irreversible and it requires a general consensus in order to succeed. Moving a population along with him on this means that the pace of reform has to be slow and, because the changes envisaged challenge an entrenched old order, sometimes painfully difficult. As the 55-yearold Miguel Díaz-Canel, the current vice president and Castro's most likely successor, has noted, Cuba has made "progress on the issues that are easiest to solve," but "what is left are the more important choices that will be decisive." (Triana Cordoví and Wilkinson, 2013)

Among the fundamental dilemmas facing the Communist leadership are the following: How can they attract and manage the foreign investment the island urgently needs without sacrificing sovereignty? How much inequality can be tolerated in exchange for higher productivity and greater opportunities? Will greater economic freedom, more transparency, public accountability, and democratic participation lead the country to some form of liberal democracy, rather than socialism? On the other hand, if the reforms morph Cuba into a state capitalist success will the United Sates tolerate that kind of Cuba any more than it has a socialist one? Much depends on the behaviour of the Northern neighbour.

From the moment he assumed provisional power in 2006, Raúl Castro has consistently talked about the predicament. "We reform, or we sink," he declared in 2010. (Voss, 2010) Although the Communist Party remains the sole political party, terms such as "decentralization," "accountability," and "institutionalization" have fully entered the political discourse. In the 1990s, only limited private enterprise was allowed, but now the government has an official 
target of eventually having 50 percent of GDP in what it terms the 'non-state sector'. Such goals would have been considered beyond the pale less than twelve years ago. But now the representation of Cuban small-business owners in the National Assembly and the participation of the self-employed in the annual May Day parade is evidence that the move towards the market is permanent. (Thale and Boggs, 2013)

The reforms have had successes. In the wake of the 2008 global financial crisis, Cuba succeeded in restoring financial stability, resumed its debt payments, and recovered growth. Several key strategic investments from international partners are moving forward on schedule. Most notably, the development of Mariel Harbour $80 \mathrm{~km}$ West of Havana, with the aid of Brazilian capital, to transform it into a major container shipping port and industrial zone. Meanwhile, a state financial accountability bureau has exposed several high level cases of corruption. (Ravsberg, 2014)

Nevertheless, the economy faces serious obstacles. Structural characteristics determine that its specific path to economic prosperity cannot follow China or Vietnam's. (Wilkinson, 2012) Unlike those two countries, when they started their reforms, Cuba is an underdeveloped country with developed-world problems. The population is ageing (18 percent of the population is over 60), and the economy is heavily tilted toward the services sector. When Vietnam began its doi moi economic reforms in 1986, services accounted for about 33 percent of GDP, whereas the productive base represented nearly 67 percent. By contrast, services in Cuba make up close to 75 percent of the island's GDP. Service exports (mainly of health-care professionals), combined with tourism and remittances are now the main sources for foreign exchange earnings. The overseas health care sector is heavily dependent on Venezuela which is undergoing serious political and economic turmoil. (Piccone and Trinkunas, 2014)

Cuban leaders recognize this structural weakness and emphasize the need to boost manufacturing and foster a broader export sector along with a more dynamic domestic market. But in all these, the problem boils down to a lack of investment and the lack of close export and import market, for which in the post-Cold War era, the policy of the United States is largely to blame. For Cuba to really develop therefore requires the barriers to foreign trade and investment that the US embargo imposes to be lifted. Optimism that this will happen now that Trump is in the White House and the Republican Party controls both Houses of Congress has somewhat evaporated.

What is certain however, is that while it may raise or ease living standards, the expansion of the small-business sector and an internal market in the production and distribution of consumables will not resolve the core structural problem. Nor is this expansion anywhere near a completely free market that would be endorsed by the advocates of such development models. The government has permitted 201 legal categories for self-employment, but these are concentrated almost exclusively in the services sector, including proprietors of independent restaurants, food stands, and bed-and-breakfasts. Fees for required licenses are high and some of the legal categories are oddly specific - e.g. palm tree trimmer or children's clown. (Feinberg, 2013)

The expansion of self-employment, while impressive, has not yet enabled the state to meet its targets for slimming down its payrolls. In late 2010, Raúl Castro wanted to eliminate 
500,000 state jobs in the first six months of 2011 , with an eye to incorporating over 1.8 million workers (out of a total estimated work force of 5.3 million) into the private sector by 2015 . But the government managed to eliminate only 137,000 positions in the first year. Small businesses in 2016 employed some 402,000 citizens, an increase of more than 150 percent since the liberalization began in 2010 but well short of the target. (Mulet Concepción, 2016)

The island desperately needs to rebuild its agriculture. Before Raúl Castro came to power, approximately 20 percent of the cultivatable land in the country lay fallow and the island imported 80 percent of its food. Unlike China and Vietnam where a rural peasantry still comprises a majority of the working population, Cuba's legacy of plantation agriculture means the countryside is depopulated. Despite rapid industrialisation, even today more than 50 per cent of China's population is engaged in peasant farming, whereas in Cuba the population is more than 70 per cent urbanised. (Wilkinson, 2012) Thus, while China's development was based upon the rapid urbanisation of a rural poor willing to work in manufacturing plants for low wages, Cuba needs to do the reverse and encourage an urbanised, professionalised population into the fields to boost food production. To do this, the state has handed over more than 3.7 million acres of land to individuals to farm. It gave some 200,000 people between 120 and 240 hectares under usufruct. It also gave the already existing 120,000 private farmers more land. The private farmers' crops account for 57 percent of the total food production in the country despite their occupying just under 25 percent of the arable land. As yet, despite these reforms, aggregate food-production levels in many basic categories in 2016 still hovered at 2002 levels. (World Food Program,2016)

More promising is the investment to renovate Mariel Harbour to the West of Havana. This project is led by the Brazilian conglomerate Odebrecht, with backing from the Brazilian National Development Bank to the tune of US\$600 million. Cuba is hoping to position itself as a major shipping hub in the Caribbean. Located between the Panama Canal and Brazil, the United States and Europe, the enormous, deep-water port at Mariel is ideally situated to handle trade in a post widened Panama Canal world. (Miller, 2016)

The port project underscores some of the dilemma as constraining foreign investment in Cuba and the country's overall growth prospects. Havana has designated Mariel as a special economic development zone - an area where foreign companies are given special incentives and prerogatives - in an effort to attract investment. Four Brazilian pharmaceutical companies have signed to produce medicines in the port's vicinity for direct export to Brazilian and other markets. Seven Mexican firms have announced they are setting up in Mariel and the Chinese are said to be considering locating a Geely car plant there. However, because the U.S. is the island's natural and most neighbouring market, if the U.S. embargo remains in place, the longterm benefits of the Mariel investment will be limited. The Brazilians have said that the investment only really makes sense if the US lifts its embargo. Cuban officials also aim to take advantage of the country's well-educated population and industries in the zone geared toward high-tech innovation and other high-value-added activities, such as biotechnology. However, yet again, the success of such ventures will depend on the opening of the U.S. market to Cuban gods and services. (Feinberg and Piccone eds. 2016)

The island's dual-currency system makes the challenge all the more difficult. A by-product of the circulation of U.S. dollars in the 1990s - first in the black market, then legally - the Cuban 
convertible peso (CUC) today functions as the currency of the tourist sector and is required for the purchase of many consumer items. For common Cuban citizens, the value of the CUC is pegged to the dollar, with one CUC roughly equal to 25 Cuban pesos (CUP), the currency in which most state workers are paid. Consequently, citizens who receive hard currency from abroad or who earn money in CUC, such as workers who collect tips from foreign tourists, or who work in key foreign currency earning industries such as tobacco or nickel, enjoy much higher incomes than workers who rely solely on salaries paid in CUP. This imbalance has produced very marked income strata in Cuba. It is wrong to talk of these strata as classes at present, but there is a fear that the increase in private enterprise might eventually lead to the development of a new petit-bourgeoisie. There is a counter argument that hopes that a progressive taxation system will limit both the size of the enterprises and wealth of individuals and will also serve to allow for a redistribution that will reduce rather than exacerbate social inequalities. (Wilkinson, 2012)

Nevertheless, however worrying the social effects of the dual currency might be, the economic problem is worse. In order to protect CUP prices from inflation the values of the CUC and the CUP are considered equal in exchanges within and between state enterprises. This strange accounting practice was helpful during the depths of the economic crisis that followed the collapse of the Soviet Union, but today it makes it difficult for analysts and investors to estimate the real costs of doing business on the island, or the value of state companies, and therefore acts as an obstacle to foreign investment. A move to unify the currencies is therefore understood as essential to future growth. Economists agree that the least disruptive way to move toward a single currency would be to gradually merge the two exchange rates in tandem with a steady rise in GDP and salaries overall. The problem therefore is to raise the productivity of the Cuban economy to the point that it can sustain such a convergence. Once again, without a retraction of the U.S. embargo it is very difficult to see how this can be achieved. (Economist, 2013)

Cuba's reform of its migration law in 2013 neatly illustrates the possibilities, limits, and implications of the situation. Faced with an exodus of educated professionals from the country after the revolution, the Cuban government heavily regulated the movement of its citizens abroad. In view of the emigres' direct involvement in attempts to overthrow the Castro government, often financed and trained by the U.S. government, Cuba treated migration as a matter of national security. For many years, those who succeeded in leaving, legally or illegally, had their property removed by the state and could not, except in extraordinary exceptions, return.

However, today it has been a long time since Cubans on the island and off could be neatly divided between anti-communists and pro-Castro revolutionaries. Successive waves of migration in the 1980s and 1990s have increased the size and altered the composition of the Cuban community that lives beyond its borders. The strength of transnational ties has grown enormously. For example, in peak season today, over a hundred weekly flights carry Cubans and Cuban Americans between Miami and Havana alone. Such travel, allowed under some circumstances since the late 1970s, has expanded considerably since 2009, when Barack Obama lifted restrictions on family visits. In 2014, some 460,000 Cubans in the United States visited the island. This is to say nothing of the hundreds of thousands of Cuban emigrants 
living across Latin America, Canada, Europe, and beyond who also visit and support family at home.

It is often said that Raúl Castro is a pragmatist, and here we may see an example of his pragmatism at work. By making it easier for Cubans to travel, work abroad, and then return home, Cuba's new migration law is ostensibly meant to stimulate the economy. At an estimated minimum of $\$$ US1 billion a year, remittances have been extremely important since the late 1990s in helping Cubans to compensate for low salaries and to take advantage of the opportunities for private enterprise. However, now that the government has undertaken a wider expansion of the small-business sector, ties between the diaspora and the island are bringing a political payoff. Cubans abroad are helping by investing money in the window-front cafeterias, repair shops, and other small businesses that are now emerging across the island. Some islanders are also sending their own money out of the country so that relatives can buy them consumer goods and supplies for their businesses. This increases both the size of the stake and the number of stakeholders living in the United States who are invested in the newly emerging private sector in the island. Their interests are in being able to return to the island and to share in the profits, so they are inclined therefore to support any US government that wishes to increase engagement with the island. In this way, the migration policy can be seen as a way for the Cuban government to assist and encourage Washington to relax the embargo further.

From the Cuban government's point of view the move is a gamble. Opening the doors for more young citizens to leave could prove a huge problem for the quickly ageing, low-birthrate society that has been suffering from a brain drain for some time. (Miroff, 2009) Medium to long term, this out migration needs to be stopped and reversed but to do that requires a thriving economy with rewarding employment and career prospects for the young. To achieve that, as has been explained, Cuba urgently needs capital investment. But because the natural market for Cuban exports and imports is the United Sates, this can only happen if the U.S. lifts its embargo. So to some extent the new migration law is a risky gambit to help stimulate a change in U.S. policy before the drain of the working age population has a seriously deleterious effect. In this regard, a reversal of the Obama policy under Trump could have serious demographic consequences.

Equally difficult for Cuba is striking a balance between the market and state presents. Steps are tentative and reactive. Recently for example, Cuba legalized the creation of transportation cooperatives - private, profit-sharing entities owned and managed by their members - to alleviate bottlenecks in agricultural distribution. Meanwhile, 100 state enterprises are now running their finances completely autonomously as part of a pilot programme. And the Communist Party is working through numerous contradictions - recognizing a place for market economics, challenging old biases against entrepreneurs, and hinting at decentralizing the budget while incongruously insisting, in the words of its official 2011 guidelines, that "central planning, and not the market, will take precedence." (Communist Party of Cuba, 2011) A new constitutional settlement was being discussed for approval at the Party Congress in April 2017 that it was said would create a political environment in which the new economic reforms will be enshrined, but which in the event did not materialise. (Whitefield, 2016) 
Cuba is therefore in a state of considerable flux and uncertainty. Questions are numerous: What is the ideal limit of the state's economic role? Is the market compatible with socialism? Can a socialist state be democratic? Hayek's hypothesis that the two are incompatible may have found a testing ground in Cuba. Hayek argued that there was an inverse proportionality in the relationship between collectivism (he preferred that term to socialism as he wanted also to include corporatism and fascism within the category) and the market: "You can have equality with unfreedom and freedom with inequality but not equality and freedom," he said. (Hayek, 1978) Here we might also see that Cuba is ironically providing a practical example of what he meant, for as the state and the goal of egalitarianism are receding there is a growth in individual freedom evident.

In Cuba, at least rhetorically, the state is determined to continue to have a macro-economic role in managing the economy and it will be much bigger than it currently is in any liberal democracy. The government promises to continue providing Cubans with social services, such as health care and education, but there is going to be a limit placed on a safety net that was huge by any standards. Indeed, Party leaders have reprimanded the island's citizens for otherwise depending too heavily on what one prominent official a few years ago called the "daddy state." (Frank, 2009) This is deeply ironic. Cuba's revolutionary founders, who built up a paternalistic state in the service of egalitarianism, are now calling for it to be dismantled.

As mentioned above, the reforms were introduced through a mass consultative process. In the run-up to the 2011 Sixth Congress of the Cuban Communist Party, the government convened a series of assemblies across the country to hear citizens' grievances and proposals for change and to discuss the future. Although multiparty elections are not on the horizon, this undertaking did allow for widespread and sometimes contentious debate, albeit still within "socialist" conceptual parameters. What is interesting about these debates was that the populace demanded the right to buy and sell houses and cars and requested the right to travel without the need for permission. All of these were policies which the state had not proposed and all of which the state has introduced. It is therefore possible on this evidence to argue that Cuba's centuries-long collective struggle for sovereignty has produced a situation in which there is a hegemony of popular opinion in favour of a single party system that allows for a much greater citizen voice and a much broader tolerance of dissent than has been visible in other socialist societies. (Ludlam, 2012)

Raúl Castro has called on public officials to make themselves accessible to the press, and he has asked the press, in turn, to criticise the failings of the leadership. In addition, he has implored students to "debate fearlessly" telling them: "the more disagreement you have, the better the decisions will be." (Boadle, 2006) More recently the government has fulfilled a promise to make public access to the internet more accessible. (BBC News, 2016)

Despite this, reality still lags behind the rhetoric. Open debate in public among high-ranking Cuban officials does not take place. Cuba's National Assembly is still not the kind of deliberative legislative branch of government that it needs to be once the executive passes under the control of a younger generation that lacks the moral legitimacy of being a revolutionary founding father. Public statements perceived to impugn the Cuban Revolution remain extremely taboo. Nevertheless, outside of high-level government bodies and the still largely docile press, diverse voices have pushed at the limits of debate. 
In 2013, a group of Catholic Bishops circulated a series of proposals for political reform online. (Catholic News Agency, 2013) These included allowing direct, competitive elections for all of Cuba's major leadership positions (albeit with all the candidates coming from the Communist Party), unrestricted access to the Internet, freer media, more effective separation of powers in the government, and greater use of referenda on major decisions. The proposals provoked opposition from some conservative Communists while generating interest, and debate among academics. The consequence was that there was a widespread expectation that the Communist Party Congress in April 2017 would approve proposals that would contain some of these ideas. This did not happen in the event and this may have therefore marked the high water mark of Cuba's liberalisation. (Whitefield, 2016).

To summarise, the question of Cuba's political future rests on whether or not the economy develops and, as has been established, this economic development is only feasible if the embargo is lifted. If Cuba prospers, then liberalisation will become possible. If it does not prosper then the state is more likely to return to greater control and repression in order to manage austerity. So the future of Cuba rests on the horns of a dilemma that can only be resolved in the United States. The question is: Will the United States lift its embargo?

\section{The U.S. move towards Cuba}

The application of economic sanctions against Cuba by the United States has encompassed almost six decades. In all, eleven US presidents have overseen the policy but it is a mistake to assume that the sanctions have remained the same in intensity throughout these years nor has it always been a means towards the same goal. The recent decompression in the embargo brought about by President Obama is unprecedented in its extent and intent, but it is not the first time relaxations of sanctions have occurred. The question is how far do the recent changes in policy reflect a change in the goals of U.S. policy towards Cuba?

To address this question in the light of recent events let us begin with the widespread belief that the embargo of Cuba has failed. This is the rationale used by Obama in announcing his intention and desire to repair relations with Havana. It has long been the view among scholars and there appears in the a widespread and long-held opinion that the embargo has not worked and is counterproductive. Sanctions expert Margaret Doxey (1975) says: "the general ineffectiveness of the [Cuba] embargoes has long been apparent". Cuba scholar Donna Rich Kaplowitz entitles her 1998 book Anatomy of a Failed Embargo (Kaplowitz, 1998). Historian Luis Pérez Jr. in 2002 called the embargo "anachronistic and anomalous" (Pérez Jr., 2002), while former diplomat Wayne Smith in the year of Obama's first victory said: "the embargo is a continuing failure" (Smith, 2008)

Former Secretary of State Madeleine Albright summarized the general consensus in suggesting that the US required:

A policy toward Cuba that is free from the political wrangling of the previous half century. The Embargo may have served a purpose originally, but it has outlived its usefulness. It currently has no international support and little function except to provide a convenient justification for Havana's repressive policies. The United States has no licence to dictate Cuba's future and heavy handed attempts to do so will only sabotage those inside Cuba who are working for democracy and human rights. (Albright, 2008, p. 
This is precisely the argument that Obama used to justify his attempt to remove the sanctions. What all these commentators have in common is the fact that they judge the embargo's success against the same yardstick: regime change - taking as given that its goal is to bring down the Communist regime and replace it with another. A closer analysis reveals that the embargo is not, nor has it ever been, the only means employed towards the end of regime change on the island. Nor has regime change always been the goal of U.S. policy.

As David A. Baldwin (1985) observed in Economic Statecraft, there is a tendency among anti-embargoists to confuse the means with the ends of US policy over Cuba (p. 188). Here, there is now a division between the executive and legislative branches. While Obama stated that the policy is no longer one of 'regime change', the US goal as it is stated in the so-called Helms Burton Law of 1996, is the replacement of the Communist regime in Cuba with a liberal democratic multi-party system and free market economy. Perhaps this apparent paradox might be explained by the fact that historically this end has not always been the embargo's purpose and nor has the embargo ever been the sole means that that has been used in pursuit of whatever goals the US has had.

Leaving aside the means for a moment we can say that the objectives of the US policy toward Cuba, despite fluctuations in design and scope, can be classified under two principle headings: overthrow and containment.

Table 1

US Cuba Policy: Fluctuating Ends and Means

\begin{tabular}{|l|c|l|}
\hline Period & End & Means \\
\hline $1960-1963$ & Overthrow & $\begin{array}{l}\text { Invasion, } \\
\text { Assassination } \\
\text { Subversion } \\
\text { Sanctions }\end{array}$ \\
\hline $1964-1991$ & & $\begin{array}{l}\text { Assassination } \\
\text { Subversion } \\
\text { Sanctions }\end{array}$ \\
\hline $1991-2008$ & Containment & Sanctions \\
& & Subversion \\
\hline $2009-16$ & Overthrow & Decompression \\
\hline $2017 ?$ & Reform within & Sanctions \\
\hline
\end{tabular}

These objectives have been pursued during different periods. In the early phase of the confrontation (approximately from 1960 to 1963) the policy of the US government was to overthrow Fidel Castro. Then, from 1964-1991 during the Cold War the policy goal shifted to one of containment as described eloquently by Bender (p. 175). Following 1991, the emphasis switched back to regime change once more. There are nuanced moments within this broad periodisation but essentially until the present moment the US has never embraced the goal of trying to accommodate itself to the Castro regime and to engendering or encouraging a reform process in Havana rather than a replacement.

In the first period (1960-1963) various means were employed to the end of overthrow with economic sanctions being only a minor part of a range of other measures that included invasion (Bay of Pigs 1961), sabotage bombings and assassination attempts. So for example, 
on 17 March, 1960, when President Eisenhower gave the orders to the CIA to prepare the Bay of Pigs invasion the instructions called for a four-pronged strategy aimed at overthrowing Castro. These were: (1) The creation of a unified political opposition to Fidel Castro outside Cuba; (2) The development of a propaganda programme including a media machine to disseminate anti-Castro propaganda inside and outside the island; (3) The creation and supply of an underground opposition within the island; and (4) The creation of a paramilitary force outside Cuba (Rodríguez, 1999, p. 21).

At the same time, Eisenhower cut the sugar quota and began trade sanctions. But these were an adjunct to these other means by which the US sought the overthrow. In fact, as $\mathrm{CIA}$ director Allen Dulles candidly confessed to UK premier Harold Macmillan, the intention of the sanctions was actually to drive Castro into the arms of the Soviets in order to make it easier to justify more bellicose methods later (Hershberg, 2000, p. 125).

US objectives changed when the military options failed to overthrow the regime. Following the settlement of the Missile Crisis in late 1962, the US accepted that it could no longer invade the island since the Soviet Union had committed itself to defending it at all costs. US policy therefore switched to one of containing the Castro revolution and thus the embargo became the chief instrument to this end.

Anti-embargoists tend to overlook the following expression of US policy goals from Under Secretary of State, George C. Ball in 1964:

(1) To reduce the will and ability of the present Cuban regime to export revolution and violence to other American states;

(2) To make plain to the people of Cuba and to the elements of the power structure of the regime that the present regime cannot serve their interests;

(3) To demonstrate to the peoples of the American republics that Communism has no future in the Western Hemisphere;

(4) To increase the cost to the Soviet Union of maintaining a communist outpost in the Western Hemisphere (Bender, 1975, p. 29).

It is for this reason that Albright said that the embargo once 'served a purpose but has outlived its usefulness' because since the Cold War ended in 1991-2 these goals (except arguably for no. 2) have either been met or have been rendered obsolete. What Albright overlooks to mention is that while she was in office in the 1990s the ends of US policy once more returned to one of regime change and the embargo was toughened precisely to serve that purpose.

Indeed, pro-embargoists argue that the economic boycott of Cuba really dates from the collapse of the COMECON in 1991. This trade bloc had sustained the Cuban socialist system and ensured that the US embargo had little or no impact. Only after its removal could sanctions really begin to work to undermine the regime and produce the conditions for systemic change (de Vrona, 1996, p. 11). It was the argument that the sanctions now had the chance to work that sustained the debates surrounding the passage of both the 1992 Cuba Democracy Act and the so-called Helms-Burton Law of 1996. These two laws had the effect and intention of increasing the intensity of the embargo and extra-territorializing it by including measures that coerce third countries and their companies into joining in. Implicit in these laws is a change of the terms upon which the embargo is justified since they both contain statements to the effect that US policy is now aimed at bringing about a 'democratic transition and a free market economy' on the island. In particular, Helms-Burton makes the 
lifting of the embargo contingent on the Cuban government undertaking such a transition. The President is therefore hind bound by Congress not to lift the embargo until certain conditions are met, which include the removal of the Castro brothers from power and the disbanding of the Cuban Communist Party.

Latterly therefore, more than twenty years after Helms-Burton was passed, with a Castro brother still in power and the regime intact, it has become evident that this objective of regime change has not been achieved. Furthermore, since the US agricultural lobby succeeded in forcing an exception to the embargo in 2000 to allow US farmers to sell Cuba food, anti-embargoists have been able to ridicule the policy by saying that in effect the embargo no longer exists: "How can you starve a people into submission and feed them at the same time?"

But this debate is really about ends not means because to be accurate it should be recognized that the economic sanctions are not the only means being employed to achieve the outcome. The subversion methods that Eisenhower authorized in March 1960 are still employed and are very much still part of US strategy in its confrontation with Havana. This includes generous funding for radio and TV stations that beam propaganda at the island, and support for the Cuban internal opposition and groups in Miami that are opposing the regime. As Baldwin argues, it is not the embargo alone that should be blamed for the failure of achieving the goals when other means employed are ignored. (Baldwin, 1985, p. 188). So the question is one of altering the goal of the policy and not the means. The embargo is useless as a tool of overthrowing the Castro regime, but economic sanctions might be useful in encouraging it to reform itself.

There is a hint of this in Albright's opinion where she talks about the way in which the embargo "sabotages those inside Cuba who are working for democracy". Implicitly she is suggesting that internal reform in Cuba is being stifled by the 'heavy-handedness' of the current policy. What is being suggested therefore is perhaps a shift in the goals rather than the embargo itself.

Barack Obama, by relaxing some aspects of the embargo and holding talks with Raúl Castro clearly signalled this as the executive will. However, as the voices behind President elect Trump have proved, there are still considerable forces within Congress who defend the goal of overthrow arguing that although the objective has not been met yet, this does not mean that economic sanctions will not work sometime in the future, or that they might actually be slowly working in bringing about the conditions for the eventual transformation of the regime.(Borger, 2016) ${ }^{2}$

Absent the use of military force there a few ways one government can easily or swiftly bring about the demise of another. Daoudi and Dajani, in their study of sanctions policies, note that sanctions as an alternative to force, while not bringing about the desired demise, nevertheless perform seven important functions in the short term:

(1) Maintaining the perception that the sanctioner is inflicting damage to the target;

(2) Expressing morality and justice;

(3) Signifying disapproval and displeasure;

(4) Satisfying the emotional needs of the sanctioner;

(5) Maintaining the sanctioner's positive image and reputation;

(6) Relieving domestic pressure on the sanctioner;

(7) Inflicting symbolic vengeance (Daoudi \& Dajani, 1983, p. 161).

\footnotetext{
${ }^{2}$ Donald Trump appointed a hard-line Cuban American to his transition team. Mauricio Claver-Carone is an opponent of Obama's policy and has openly said that it should be reversed.
} 
Taking each of these in turn we can see that the embargo on Cuba still fulfils these functions for the US in some way.

(1) As we have seen the Cuban economy is severely affected by the shortages caused and the expense it takes to overcome them. A Cuban official put the cost of the embargo at $\$ 93$ billion (Montesinos, 2008);

(2) The question of morality is ambiguous. Of course, the embargo, from the point of view of the Cuban population on the island and many in the international community who oppose it, is highly immoral. But it is not immoral from the point of view of those in the United States who lost property when the revolutionary regime nationalised it. The embargo was imposed as retaliation for the nationalisations and it offers a means of restitution. Serving this lobby in the US has been a primary reason why the embargo has been maintained and compensation for the nationalisations is a prominent topic in the discussions between the two countries started by Obama recently.

(3) It is an abiding aim of the US to express its distaste for Communism in the hemisphere. Post-Cold War it also wished to express its displeasure to its allies for 'rescuing' the island from economic meltdown. Joaquin Roy among others has argued strongly that The Helms Burton Law was an expression of the Monroe Doctrine and aimed as much at staunching European and Canadian investment in Cuba as against the island itself (Roy, 2000, p. 6);

(4) There is an emotional element to the embargo that is often overlooked. The superpower had to be seen to be doing something to discipline this upstart in its backyard. In addition after failing to support its surrogates in the 1961 Bay of Pigs invasion, Washington has had a debt to repay to the exiles. This is turn, has given them a privileged status, which they have exploited to affect policy decisions in Washington;

(5) Image and reputation are very important. As Baldwin (1985) pointed out: “... the intrusion of a "communist outpost" in the hemisphere threatened the US world image no matter what it did or did not do. Doing nothing would have entailed costs in terms of US reputation for action" (p. 185);

(6) Though the anti-Castro lobby in Florida is divided and thereby has lost some of its steely grip, there is no doubt that the hardening of the embargo in the 1990s came about as a result of the pressure from this constituency, cleverly using its electoral decisiveness in a highly valuable swing state to its advantage (Vanderbrush \& Haney, 1999);

(7) There can be little doubt there has been an element of vengeance in the policy. Fidel Castro cannot be forgiven for the humiliation he inflicted.

Daoudi and Dajani then list three objectives that sanctions meet in the medium term:

(1) Inflicting economic damage on the target - in the case of Cuba this is indisputable;

(2) To use the target state as an example to others - this was one of Ball's objectives in 1964;

(3) Restoring the sanctioner's self-confidence and image - It is often argued that the embargo is a mistake because it damages the US's image, but as Baldwin (1985) pointed out, given the challenge the Cuban revolution represented to US power and influence in a region it considers its 'backyard', the US could not do nothing. Outright invasion of Cuba would have removed Castro but would have been much more costly in terms of damage to its image, especially in Latin America. Thus the embargo has been the most cost effective policy to adopt in order to maintain US authority. 


\section{Concluding thoughts}

It is important to understand that the international context in which the embargo operates has now changed. In terms of world opinion, the US has been consistently condemned for its embargo at the UN General Assembly. In the latest vote in October 2016 the Obama administration abstained on the resolution that condemned its own policy! It meant it passed unanimously. (Sengupta and Gladstone, 2016) The US is also isolated at the Organisation of American States, where the rest of the Americas have insisted the embargo should end. More importantly, as discussed above, although the political regime is still intact, the Cuban economic system has changed since the 1990s. The reaction to the collapse of the Soviet Union was for Cuba to adopt economic reforms that have liberalized the economy, allowed for foreign capital investment and the relaxation of some crucial pillars of the egalitarian socialist centrally planned system. Private enterprise is now allowed and a relaxation in the area of artistic and religious freedom has taken place. Because the Cuban government has admitted that it made these changes in order to survive, it is arguable that it was the embargo that made these reforms necessary. If this is true, then this becomes an argument for keeping the embargo rather than lifting it, it also means that the embargo could be a tool to induce regime reform rather than overthrow.

In their study Daoudi and Dajani (1983) pointed out that the benefits of economic sanctions are often overlooked. They suggest that the "bull's eye" of sanctions policies generally is to overthrow the target government and because the sanctions often miss this target, they are perceived to have failed (see Figure 1). This "bull's eye fallacy" has produced a paradigm in which sanctions are generally viewed as being ineffective instruments when in fact they fulfil a variety of other valuable objectives. In the case of the embargo of Cuba, it is clear that the embargo has fulfilled a range of these objectives. It expressed US determination not to accept Communism in the hemisphere, it helped to contain and prevent the spread of single-party Communist systems and U.S. prestige as the regional hegemon was sustained. Furthermore, the embargo inflicted damage on the Cuban economy and there is no doubt that the Cuban government wants to see it lifted. This fact alone testifies to its effectiveness. If it did not hurt it would not matter. Equally important to note is the fact that if it was not there it could not be lifted. It therefore gives the US leverage against the Havana regime (Daoudi \& Dajani, 1983).

So how long will the embargo last? It would seem from this analysis that it might last in some form for some time because it fulfils a number of very important symbolic and emotional needs. This is true on both sides of the Florida straits. In a sense one can view the embargo as a pathological symptom. In Melanie Klein's definition it is possible to see Washington and Havana as displaying 'paranoid-schizoid' tendencies by projecting outwards feelings of badness onto the other (Klein, 1985). There is a symbiotic relationship between the adversaries which is discernible in the protracted difficulties they have had in reaching agreement on issues. For the US the cost of lifting the embargo without exacting some credible step towards the goal of regime transformation in the island is for many tantamount to admitting defeat. For the Cuban government succumbing to any US demands to earn the 'reward' of having the sanctions lifted is likewise symbolically difficult.

There is of course the remote possibility that the Cuban people will reject the Communist government, there is also a slight possibility that the leadership might divide on the issue of democratic reforms, but neither of these scenarios seems likely to occur while one of the Castro brothers remains alive or while if U.S. hostility returns. For the U.S. part, the fact that the last Castro brother is now nearing death means that an incentive for the U.S. to keep up 
pressure or the threat of it remains.

Regardless of who is in the presidency therefore, no U.S. administration would find it easy to entirely lift the sanctions while Cuba continues with a strong state run by a single party. Without a lifting of the embargo, Cuba may succeed in producing greater economic prosperity that may be enough to satisfy the population's immediate needs but which will be insufficient to deal with the medium to long term threats to the island's stability. For this reason, Cuba may continue to liberalise but it will be gradual, pragmatic and in response to circumstances.

On the U.S. side, in pursuit of this end, even under Trump, some easing of embargo restrictions may continue, as a reward to the Cuban government for further liberalisations, or as a destabilising step in order to precipitate change. However, given the early indications this appears to be less likely than was anticipated and the reverse process is now feared. Thus the basic fabric of the embargo, as established by Congress in the Helms Burton Law, is likely to remain intact, and possibly reactivated if Havana does not respond to U.S. demands. This is precisely the position enunciated by Donald Trump shortly after the death of Fidel Castro.

\section{References}

Albright, M. (2008). Memo to the president elect. New York: Harper Collins. Baldwin, D. A. (1985). Economic statecraft. Princeton University Press.

BBC News (2016). 'Cuba announces home internet scheme in Havana.' 19 Dec. 2016.

http://www.bbc.co.uk/news/world-latin-america-38372814 accessed 24/12/16

Bender, L. D. (1975). The politics of hostility: Castro's revolution and United States policy. Puerto Rico: Inter American press, Hato Rey.,

Boadle, Anthony(2006), 'Raúl Castro calls for more policy debate in Cuba.' Washington Post, 20 December 2006. http://www.washingtonpost.com/wpdyn/content/article/2006/12/20/AR2006122001825.html accessed 23/12/16

Borger, Julian, (2016). 'Donald Trump threatens to freeze US Cuba-thaw days after Castro's death.' The Guardian 28 Dec. 2016. https://www.theguardian.com/usnews/2016/nov/28/donald-trump-cuba-sanctions-reforms-fidel-castro-death accessed $23 / 12 / 16$

Breslin Sean, 2011. 'The "China model" and the global crisis: From Friedrich List to a Chinese mode of governance'. International Affairs 87:6. Pp. 1323-1343

de Vrona, A. L. (1996). Propaganda and reality: A look at the US embargo against Castro's Cuba. Miami: Cuban American National Foundation.

Catholic News Agency, (2013). 'Cuban Bishops call for political reform, open US policy' 18 Sept. 2013. http://www.catholicnewsagency.com/news/cuban-bishops-call-forpolitical-reform-open-us-policy/ accessed 23/12/12

Communist Part of Cuba, (2011). 'Resolution on the Guidelines of the Economic and Social Policy of the Party and the Revolution' http://www.cuba.cu/gobierno/documentos/2011/ing/l160711i.html accessed $\underline{23 / 12 / 16}$

Córdoba, José (2016) 'Castro Offers Tough Appariasal of Cuba's Slow Progress on Economic Reforms.' Wall Street Journal, 16 April, 2016. http://www.wsj.com/articles/castrooffers-tough-appraisal-of-cubas-slow-progress-on-economic-reforms-1460848872 accessed 23/12/16

Daoudi, M. S., \& Dajani, M.S. (1983). Economic Sanctions: Ideals and experience. , London: Routledge and Kegan Paul. 
Doxey, M. P. (1975). Sancitons revisited. International Journal: Canada's Journal of Global Policy Analysis, 31, 53-78. doi:10.1177/002070207603100105

Economist, The. (2013) 'Cuba's Currency: Double Trouble.' Economist.com Amercia's View Blogspot http://www.economist.com/blogs/americasview/2013/10/cubas-currency accessed 23/12/16

Feinberg, Richard (2013). Soft Landings in Cuba: Emerging Entrepreneurs and Middle Classes, Brookings Institute, Washington DC.

Feinberg, Richard and Piccone T. eds.(2016) Cuba's Economic Change in Comparative Perspective, Brookings Institute, Washington DC. https://www.brookings.edu/wpcontent/uploads/2016/06/Cubas-Economic-Change-English-web-1.pdf accessed 23/12/16

Frank, Mark. (2009). 'Cuba forced to rethink system of paternalism' Financial Times, 17 Sept. 2009. https://www.ft.com/content/00d0225e-a3bc-11de-9fed-00144feabdc0

Accessed 23/12/16

Goldberg, Jeffrey. (2010). 'Fidel: Cuban model doesn't even work for us any more' The Atlantic, 8 Sept. 2010. Available at: http://www.theatlantic.com/international/archive/2010/09/fidel-cuban-modeldoesnt-even-work-for-us-anymore/62602/ accessed 30/10/2016

Hayek, Friedrich von, (1978) Interview with Tom Hazlett, http://www.hayek.ufm.edu/index.php?title=Category:Tom Hazlett accessed 23/12/16

Hershberg, J. G. (2000). Their men in Havana: Anglo-American intelligence exchanges and the Cuban crises 1961-1962. Intelligence and National Security, 15(2), 121-176.

Jones, Sam. (2016). 'Castro's legacy and the envy of many nations: Social care in Cuba.' The Guardian, 27 November 2016. https://www.theguardian.com/world/2016/nov/27/castros-legacy-and-the-envy-ofmany-nations-social-care-in-cuba accessed 23/12/16

Klein, M. (1985). Our adult world and its roots in infancy. In A. D. Colman \& M. H. Geller (Eds.), Group relations reader 2 (pp. 5-19). Washington DC : A. K. Rice Institute Series.

Vanderbrush, W., \& Haney, P. J. (1999). Policy toward Cuba in the Clinton administration. Political Science Quarterly, 114(3), 387-408.

MercoPress. (2016) 'Raúl Castro's Cuba allows farmers to hire workers directly.' 17 Dec. 2016. http://en.mercopress.com/2016/12/17/raul-castro-s-cuba-allows-farmers-tohire-workers-directly accessed 24/12/16

Nuccio, R. A. (1999). Cuba: A US perspective. In R. N. Hass (Ed.), Transatlantic tensions: The United States, Europe and problem countries (pp. 7-28). Washington DC: Brookings Institute.

Vanderbrush, W., \& Haney, P. J. (1999). Policy toward Cuba in the Clinton administration. Political Science Quarterly, 114(3), 387-408.

Kaplowitz, D. R. (1998). Anatomy of a failed embargo: US Sanctions against Cuba. Lynne Reiner Boulder.

Ludlam, Steve. "'Reordenamiento, Lineamientos Arriba': Legitimacy and Political Culture in Cuba's Reform Strategy." International Journal of Cuban Studies, vol. 4, no. 3/4, 2012, pp. 242-259. www.jstor.org/stable/41946010.

Miller, Greg. (2016). 'Cuba's Mariel port has ambitious plan to become giant feeder hub.' JOC.com, 4 July, 2016. http://www.joc.com/port-news/international-ports/cubasmariel-port-has-ambitious-plan-become-giant-feeder-hub 20160704.html accessed 


\section{$23 / 12 / 16$}

Miroff, Nick (2009) 'Cuba Going Gray: Demographic Time Bomb?' Minneapolis Post 8 July, 2009. https://www.minnpost.com/global-post/2009/07/cuba-going-graydemographic-time-bomb accessed 23/12/16

Montesinos, P. (2008). Bloqueo de EEUU impide a Cuba asumir los pagos de su deuda externa. Retrieved from http://www.cubadebate.cu/index.php?tpl=design/opiniones.tpl.html\&newsid_obj_i $d=12664$

Mulet Concepción, Yalineis, (2016) 'Self-employment in Cuba: between informality and entrepreneurship - the case of shoe manufacturing' Third World Quarterly Volume 37, No. 9 Pages 1713-1729.

Obama, Barack. 2014. 'Statement by the President on Cuba Policy Changes' White House, 14 December,2014. Available at:

https://www.whitehouse.gov/the-press-office/2014/12/17/statement-president-cubapolicy-changes accessed 30/10/2016

Pérez Jr., L. A. (2002). Fear and loathing of Fidel Castro: Sources of US Policy toward Cuba. Journal of Latin American Studies, 34(2), 227-54.

Piccone Ted and Trinkunas H. (2014). The Cuba-Venezuela Aliance: The Beginning of the End? Brookings Institute, Washington DC. https://www.brookings.edu/wpcontent/uploads/2016/06/CubaVenezuela-Alliance-Piccone-Trinkunas.pdf accessed 23/12/16

Ravsberg, Fernando (2014) 'Cuba's Anti-Corruption Effort Turns Five,' Havana Times 3 July, 2014 http://www.havanatimes.org/?p=104630 accessed 23/12/16

Rodríguez, J. C. (1999). The bay of pigs and the CIA. Melbourne: Ocean Press,

Roy, J. (2000). Cuba, the United States and the helms-burton doctrine: International reactions. Miami: University Press of Florida

Sengupta, Somini and Gladstone R. (2016) 'U.S. abstains in U.N. Vote Condemning Cuban Embargo' New York Times, 26 Oct. 2016.

http://www.nytimes.com/2016/10/27/world/americas/united-nations-cubaembargo.html? $r=0$ accessed 24/12/16

Smith, W. S. (2008). It's time to talk to Cuba. The Atlanta Journal Constitution. Retrieved from http://ciponline.org/cuba/Op-eds/022408ItsTimeToTalkToCuba.htm

Thale Geoff and Boggs C. (2013) Labor Rights and Cuba's Economic Reforms, Washington Office on Latin America, Washington DC.

https://www.wola.org/sites/default/files/Labor Rights and Cubas Economic Reforms.pdf accessed 23/12/16

Triana Cordoví C. Juan, and Wilkinson S. 2013 'A Lot Done but Much More to Do: An Assessment of the Cuban Economic Transformation So Far.' International Journal of Cuban Studies, vol. 5, no. 2, 2013, pp. 117-139. www.jstor.org/stable/10.13169/intejcubastud.5.2.0117

Voss, Michael, (2010). 'Raúl Castro says Cubans must back economic reforms' BBC News 18 Dec. 2010. http://www.bbc.co.uk/news/world-latin-america-12029873 access $\underline{23 / 12 / 16}$

Whitefield, Mimi. (2016) 'Cuba's Communist Party Congress Wants Change, but also More of the Same' Miami Herald, 18 April, 2016.

http://www.miamiherald.com/news/nationworld/world/americas/cuba/article72522672.html accessed 23/12/16

Wilkinson, Stephen. (2012) 'Neither Beijing Nor Hanoi but a Cuban Market Socialism?' International Journal of Cuban Studies, vol. 4, no. 3/4, 2012, pp. 260-268. www.jstor.org/stable/41946011 
Wootson Jr. Cleve R. (2016) 'How Donald Trump responded to the death of Fidel Castro, "a brutal dictator."' Washington Post 26 Nov. 2016.

https://www.washingtonpost.com/news/the-fix/wp/2016/11/26/here-is-donaldtrumps-reaction-to-fidel-castros-death/?utm term $=.5 \mathrm{~d} 5417$ ed0610 accessed 23/12/16.

World Food Program (2016). WFP Cuba: Country Brief, November 2016

http://reliefweb.int/report/cuba/wfp-cuba-country-brief-november-2016 accessed 23/12/16 